\title{
Fiscal Decentralization and Regional Financial Efficiency: An Empirical Analysis of Spatial Durbin Model
}

\author{
Jianmin Liu, ${ }^{1,2}$ Xiaomei Hu, ${ }^{1}$ and Hongli Tang ${ }^{1}$ \\ ${ }^{1}$ College of Economics and Trade, Hunan University, Changsha, Hunan 410079, China \\ ${ }^{2}$ Hunan University of Finance and Economics, Changsha, Hunan 410025, China \\ Correspondence should be addressed to Xiaomei Hu; hxmxiaomeihu@hnu.edu.cn
}

Received 18 January 2016; Accepted 19 April 2016

Academic Editor: Alicia Cordero

Copyright (c) 2016 Jianmin Liu et al. This is an open access article distributed under the Creative Commons Attribution License, which permits unrestricted use, distribution, and reproduction in any medium, provided the original work is properly cited.

\begin{abstract}
Based on panel data covering the period from 2003 to 2012 in China's 281 prefecture-level cities, we use superefficiency SBM model to measure regional financial efficiency and empirically test the spatial effects of fiscal decentralization on regional financial efficiency with SDM. The estimated results indicate that there exist significant spatial spillover effects among regional financial efficiency with the features of time inertia and spatial dependence. The positive promoting effect of fiscal decentralization on financial efficiency in local region depends on the symmetry between fiscal expenditure decentralization and revenue decentralization. Additionally, there exists inconsistency in the spatial effects of fiscal expenditure decentralization and revenue decentralization on financial efficiency in neighboring regions. The negative effect of fiscal revenue decentralization on financial efficiency in neighboring regions is more significant than that of fiscal expenditure decentralization.
\end{abstract}

\section{Introduction}

Improving financial efficiency via financial innovation is an important way to break the limitation of financial resource. With the effects of market-oriented economy, "voting with their feet" mechanism, the flowing of financial resources, and so on, the regional financial competition is increasingly characterized as the financial efficiency competition driven by financial innovation. Unlike the dominant direct competition of regional financial services and competitive growth of the number of regional financial institutions, financial efficiency competition is mainly reflected in the implicit indirect competition of the financial development model and financial ideas. This competition focuses on environmental and institutional factors and pursues improving spatial allocation efficiency brought by the financial resources readjustment through removing the constraints of various factors. As one of the vital institutional factors, fiscal decentralization will influence the adequacy of the local governments' fiscal resources and the behaviors of local governments to some extent, thus affecting the flowing of scarce financial resources and regional distribution of financial innovation. On one hand, fiscal decentralization between governments is helpful to induce technology diffusion, spillover effect of innovation, and competition effect among regions, which is conducive to improving regional financial efficiency while enhancing the positive external effects of financial innovation. On the other hand, local governments' excessive or inappropriate intervention under the fiscal decentralization system will result in the loss of financial innovation's leading role [1], which is detrimental to the improvement of financial efficiency. The topics on what effects the existing fiscal decentralization system may have on the regional financial efficiency among the regional financial strategic competition and how to improve financial efficiency and achieve balanced financial development among regions by optimizing the fiscal decentralized structure are worthy of our further research.

From a general survey of relevant research, it is not difficult to find that people pay close attention to research regarding the fiscal decentralization and regional financial development in terms of the relationship, mechanism, effect, and so on. Scholars have reached a consensus that the fiscal decentralization brought by the launch of tax federalism 
reform in 1994 has strengthened the local governments' intervention in the financial sectors [2-7]. Most scholars suggest that the local governments will intervene the allocation and use of financial capital directly or indirectly to obtain scarce financial resources among the regional competition in the context of fiscal decentralization system, considering their own fiscal pressures and the competition for regional GDP [8]. The consequences of governments' intervention in the financial sector are mainly reflected in the impact on the allocation efficiency of resource. Chen et al. [9] and Ding and $\mathrm{Fu}$ [10] suggested that the impact is negative, which results in a reduction of allocation efficiency of financial capital. Yin et al. [11], Yu and Pan [12], Wang et al. [13], and Y. X. Jiang and R. B. Jiang [14] also hold the same opinion. The further research of Yang et al. [15] found that the impact of fiscal decentralization on allocation efficiency of financial resources stemmed from the degree of integration between fiscal decentralization reform and market autonomy regulation and also originated from the local governments' regulatory capacity. However, the strength of local government's intervention in financial sectors varies from region to region due to the differences of economic ownership structures and fiscal pressures [16-18]. Some scholars like Chen et al. [9], Zhou et al. [19], and Wang et al. [13] carried on the discussion about the relationship among fiscal decentralization, financial development, and economic growth. They found that local governments' intervention in financial sectors hindered the economic growth in the context of fiscal decentralization system [20-22]. Currently, the difference of regional financial development caused by fiscal decentralization has become a research emphasis. By constructing an endogenous growth model including financial sectors and fiscal decentralization arrangements, Wang and Li [23] suggested that fiscal decentralization plays positive influence on regional financial development in the eastern regions, while the effects in the central and western regions are negative. The research of Zhang and Qin [24] found that the economic growth effect of fiscal decentralization on financial development varies from region to region; namely, the effects in the western and northeastern regions are positive while the effects in the eastern and central regions are negative. Ma et al. [25] also suggested that there exist significant regional differences in the long-term relationship among fiscal decentralization, financial development, and economic growth. To further reflect the mutual influence among regions, Y. X. Jiang and R. B. Jiang [26] measured provinces' regional financial innovation with the use of efficiency method and then tested spatial external effects of regional financial innovation by spatial econometric models.

From a general survey of relevant documents, it is not difficult to find that scholars pay close attention to research regarding how financial development and efficiency are affected by fiscal decentralization. Due to differences in objectives, thinking, and methodology, scholars have failed to reach a consensus regarding the impact of fiscal decentralization on financial efficiency. We briefly discuss some shortcomings in the previous literature below.

First, scholars pay more attention to social, economic, and noninstitutional factors than institutional factors including fiscal decentralization in the research regarding the impact of fiscal decentralization on financial efficiency. Second, most scholars focus on the fiscal decentralization between the central and provincial governments, and the estimation of financial efficiency is mostly concentrated in the provincial level, which may overlook some of the more detailed microscopic features. Third, most scholars used the fiscal expenditure decentralization to represent fiscal decentralization but overlooked the impact of fiscal revenue decentralization. Fourth, most scholars only paid more attention to desirable outputs while choosing the input and output indexes to measure regional financial efficiency but ignored the negative impact of undesirable outputs.

For the aforementioned reasons, we attempt to use China's prefecture-level city panel data covering the period from 2003 to 2012 to measure Chinese financial efficiency, meanwhile placing fiscal decentralization and financial efficiency into a united analytical framework, to explore the spatial external effects of fiscal decentralization on regional financial efficiency by using spatial econometric models, that is, the spatial correlations among regional competition of financial efficiency and the relationship between regional financial efficiency and agglomeration under fiscal decentralization system.

In this fashion, we hope to make the following four key contributions to the literature.

(1) Unlike the former research that found that there are differences among regional financial efficiency, we provide a more detailed perspective to comprehend spatial differences of Chinese overall regional financial efficiency by exploring the institutional causes of interaction among different regional financial efficiency, meanwhile placing fiscal decentralization and financial efficiency into a united analytical framework.

(2) We choose prefecture-level cities as the research samples. Moreover, we will investigate the fiscal decentralization from two dimensions including fiscal expenditure and revenue decentralization to make the research results more realistic.

(3) We use SBM model (Slack Based Measure, the approach of computational efficiency based on slack variables) with the features of nonradial and no-angle to measure regional financial efficiency, so as to avoid the problems that the deviation of measuring results caused by taking no account of undesirable output and impossibility of full permutation of the financial efficiency for all decision-making units (DMU).

(4) We use the SDM which synthesizes the advantages of a Spatial Lag Model (SLM) and a Spatial Error Model (SEM) to study regional spillover effects that subnational fiscal expenditure and revenue decentralization have on financial efficiency. Then, we further test for the presence of intraregion spatial spillovers using the decomposition results of direct and indirect effects, and we identify the cause of fiscal decentralization on regional financial efficiency.

The remainder of this paper is structured as follows. Section 2 measures the regional financial efficiency and analyzes the spatial clustering of financial efficiency. Section 3 builds a theoretical framework to illustrate the effects of fiscal 
decentralization on regional financial efficiency, in addition to establishing econometric models. Section 4 addresses the selection of variables. Section 5 analyzes the empirical results and engages in further comparative study. Section 6 presents conclusions.

\section{Measurement and Spatial Clustering of Financial Efficiency}

Financial efficiency refers to the input-output ratio of the financial sector. In order to pursue the goal of economic development, local governments try to maximize financial efficiency via adjusting the allocation of financial resources. The main measure methods of financial efficiency in previous research include regression analysis method, factor analysis method, and the traditional DEA method. This paper will use superefficiency SBM model considering undesirable output to measure regional financial efficiency. Different from the traditional radial DEA (Data Envelopment Analysis) model, SBM model directly introduces slack variables into the objective function to calculate the efficiency, and the economic implication of SBM model is the maximization of actual profit instead of the maximization of benefit ratio [27]. SBM model assumes that there are $n$ decision-making units, and each decision-making unit is constituted by three elements including input, desirable output, and undesirable output. The vector forms of the elements are represented as follows: $x \in R^{m}, y^{d} \in R^{r_{1}}$, and $y^{u} \in R^{r_{2}} . X, Y^{d}$, and $Y^{u}$ are matrixes. $X=\left[x_{1}, \ldots, \mathrm{x}_{n}\right] \in R^{m \times n}, Y^{d}=\left[y_{1}^{d}, \ldots, y_{n}^{d}\right] \in R^{s_{1} \times n}$, and $Y^{u}=\left[y_{1}^{u}, \ldots, y_{n}^{u}\right] \in R^{s_{2} \times n}$, where $X>0, Y^{d}>0$, and $Y^{u}>0$. Production possibility set $P$ under the condition of constant returns to scale is defined as

$$
\begin{aligned}
P & =\left\{\left(x, y^{d}, y^{u}\right) \mid x \geq X \lambda, y^{d} \leq Y^{d} \lambda, y^{u} \geq Y^{u} \lambda, \lambda\right. \\
& \geq 0\} .
\end{aligned}
$$

The SBM model based on the slack variable is expressed as follows:

$$
\begin{aligned}
& \rho^{*}= \min \frac{1-(1 / m) \sum_{i=1}^{m}\left(w_{i}^{-} / x_{i 0}\right)}{1+\left(1 /\left(s_{1}+s_{2}\right)\right)\left(\sum_{r=1}^{s_{1}}\left(w_{r}^{d} / y_{r 0}^{d}\right)+\sum_{r=1}^{s_{2}}\left(w_{r}^{u} / y_{r 0}^{u}\right)\right)} \\
& \text { s.t. } \quad x_{0}=X \lambda+w^{-} \\
& y_{0}^{d}=Y^{d} \lambda-w^{d} \\
& y_{0}^{u}=Y^{u} \lambda+w^{u} \\
& w^{-} \geq 0, \\
& w^{d} \geq 0, \\
& w^{u} \geq 0 .
\end{aligned}
$$

In (1) and (2), $s_{1}$ and $s_{2}$, respectively, represent the slack of input and output, $\rho$ is the evaluation criteria of efficiency, $w^{-}$and $w^{u}$, respectively, represent the excessive input and undesirable output, $w^{d}$ indicates the insufficient output, $m$ represents the type of input factors, and $\lambda$ represents the weight vector. Objective function $\rho$ is strictly decreasing based on $w^{-}, w^{u}$, and $w^{d}$. For a particular evaluation unit, when $w^{-}=0, w^{u}=0$, and $w^{d}=0$, that is, $\rho=1$, DMU is efficient for SBM model. When $\rho<1$, it shows that DMU is inefficient for SBM, with redundancy of input or deficiency of output. Meanwhile, Tone [27] also proposed a superefficiency SBM model, and the basic principle of superefficiency SBM model is excluding the evaluated DMU from the reference set so that the efficiency value may be greater than 1 , which made up the defect that all decision-making efficiency values cannot be calculated.

The regional financial efficiency is measured on the basis of the production method regarding the financial firms as the suppliers of financial products and services [28]. In consideration of attainability, accuracy, and consistency of data, we take labor, capital, and technology and other factors as inputs. When it comes to the output indexes, we take deposits and loans as the desirable outputs, while the income gap between urban and rural areas is regarded as the undesirable output. The selection and interpretation of indexes including input variables and desirable and undesirable output variables are as follows.

(1) The labor input of financial industry (labor): as human capital and intellectual resources of the financial industry, there is no doubt that employed persons engaged in financial industry will affect the development performance of financial industry. This index is measured by the proportion of the employees in the financial sectors account for the regional total population.

(2) The capital input of financial industry (capital): the fixed asset investment is the main fund for the infrastructure construction project in financial industry. Since it is difficult to obtain the statistics of fixed asset investment for prefecturelevel cities, we use a proxy variable measured by the proportion that the fixed asset investment accounted for in regional GDP to represent the capital input of financial industry.

(3) Information technology level (internet): the improvement of financial efficiency is dependent on the innovation and development of electronic finance, mobile finance, internet finance, and other emerging financial methods, which depend on the development of information technology. This index is represented by a proxy variable measured by the number of international internet users in cities.

(4) The desirable output of deposit (deposit): The regional financial efficiency is measured on the basis of the production method regarding the financial firms as the suppliers of financial products and services [29]. The production method takes deposit and loan as output, while the input is operating cost including labor, capital and technology. The index is represented by per capita deposit of financial institutions, where per capita deposit of financial institutions = total deposit of financial institutions/regional population.

(5) The desirable output of loan (loan): the loan of financial institutions, especially the banks, is the main source of profits for financial institutions. The index is represented by per capita loan of financial institutions, where per capita loan of financial institutions = total loan of financial institutions/regional population.

(6) The undesirable output of income gap between urban and rural (igap): The development of the financial industry 


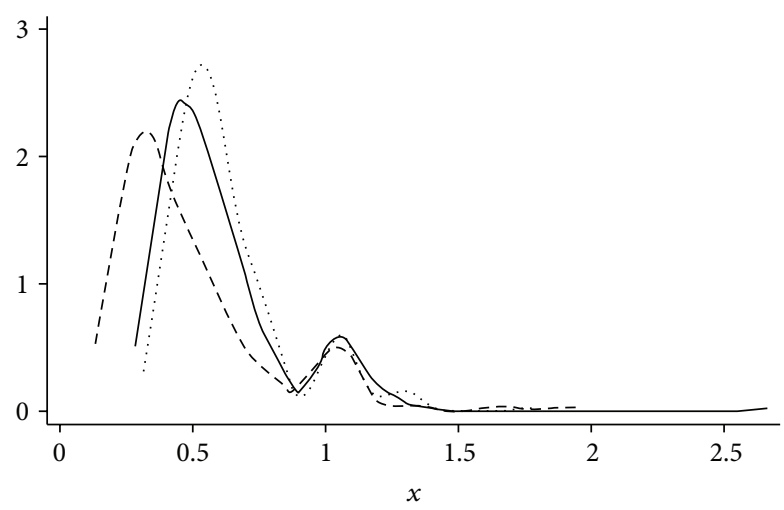

..... k density fe2003

- - - $\mathrm{k}$ density fe 2012

— $\mathrm{k}$ density fe2007

FIGURE 1: Kernel density segment curve of financial efficiency.

results in money flowing from low income groups to high income groups, due to the threshold and cost to obtain financial services and the difference between regional resources endowment, which will exacerbate income inequality, especially in developing countries. With reference to the research results of Yao [30], we take urban-rural income ratio as a proxy variable, where urban-rural income ratio = per capita disposable income of urban residents/per capita net income of rural residents.

Based on the input-output data of 281 prefecture-level cities covering the period from 2003 to 2012, this paper measures the regional financial efficiency by using MAXDEA6.4 software. The calculation results show that there exists great difference in regional financial efficiency, and the average financial efficiency is 0.576 , while the standard deviation is 0.624 . From a regional perspective, the average financial efficiency in the eastern, central, and western regions is, respectively, $0.628,0.503$, and 0.604 , and the financial efficiency of the central region is lower than that of eastern and western regions. In addition, this paper makes Kernel density estimation on regional financial efficiency in the three typical years $(2003,2007$, and 2012) by using nonparametric Gauss normal Kernel density (nuclear density) segment curve. As shown in Figure 1, the horizontal axis represents the regional financial efficiency value of prefecture-level cities, while the vertical axis represents the corresponding Kernel density values.

First, there shows tendency toward left deviation at regional financial efficiency in China's prefecture-level cities in the view of the specific distribution form, which indicates that the financial efficiency in most regions are below the national average level. Second, the main peak level of financial efficiency gradually declines and moves to the left deviation during the three typical years (2003, 2007, and 2012), which indicates that the level of financial efficiency gradually decreases while the gap between the financial efficiency of different regions is widening. In addition, China's regional financial efficiency distribution form gradually evolves from multipeak trend in 2003 to the double-peak trend in 2012,
TABLE 1: Moran's I index of regional financial efficiency.

\begin{tabular}{ccc}
\hline Year & $\begin{array}{c}\text { Geographic distance } \\
\text { weighting matrix }\end{array}$ & $\begin{array}{c}\text { Mixed geography-economy } \\
\text { weighting matrix }\end{array}$ \\
\hline 2003 & $0.152^{* * *}$ & $0.130^{* * *}$ \\
2004 & $0.094^{* * *}$ & $0.061^{* * *}$ \\
2005 & $0.094^{* * *}$ & $0.028^{*}$ \\
2006 & $0.135^{* * *}$ & $0.092^{* * *}$ \\
2007 & $0.137^{* * *}$ & $0.100^{* * *}$ \\
2008 & $0.075^{* * *}$ & $0.057^{* * *}$ \\
2009 & $0.019^{* * *}$ & $0.024^{* * *}$ \\
2010 & $0.141^{* * *}$ & $0.088^{* * *}$ \\
2011 & $0.140^{* * *}$ & $0.071^{* * *}$ \\
2012 & $0.149^{* * *}$ & $0.052^{* * *}$ \\
\hline
\end{tabular}

Note: $* * *$ and $*$, respectively, represent the significant level of $1 \%$ and $10 \%$.

which indicates that the development trend of regional financial efficiency shifts from multipolarity mode to doublepolarity mode.

In order to investigate the spatial clustering pattern and the evolution trend of financial efficiency in 281 prefecturelevel cities covering the period from 2003 to 2012, it is needed to further calculate Moran's $I$ index of regional financial efficiency by using global spatial autocorrelation method. Moran's I index is the correlation coefficient of observed values and spatial lagged variables, and the value of index ranges from -1 to 1 . If the regional financial efficiency presents spatial positive correlation, the value of Moran's $I$ index ranges from 0 to 1 , which indicates that the regions with similar observed values are collectively distributed in the spatial range. The closer Moran's $I$ index to 1 , the stronger the spatial positive correlation. On the contrary, the regions with similar observed value are discretely distributed in the geographical space. The specific measure formula of global Moran's $I$ index is as follows [31]:

$$
\text { Moran's } I=\frac{n \sum_{i=1}^{n} \sum_{j=1}^{n} w_{i j}\left(x_{i}-\bar{x}\right)\left(x_{j}-\bar{x}\right)}{\sum_{i}^{n} \sum_{j=1}^{n} w_{i j} \sum_{i=1}^{n}\left(x_{i}-\bar{x}\right)^{2}} \text {. }
$$

In (3), $x_{i}$ and $x_{j}$, respectively, represent region $i$ and region $j$ and $n$ represents the number of regions, while $w_{i j}$ represents the spatial weight matrix. We will measure regional financial efficiency with two spatial weight matrixes including geographic distance weighting matrix and mixed geographyeconomy weighting matrix in the view of robustness of research results. The specific construction methods of these two spatial weight matrixes are as in Section 4.

Table 1 lists Moran's $I$ indexes of regional financial efficiency calculated with two spatial weight matrixes. According to the estimated results, the values of Moran's I index calculated with two spatial weight matrixes are positive and pass the $10 \%$ significance test, which indicates that there exists significant positive autocorrelation (spatial dependence) among regional financial efficiency in the geographical space. The spatial distribution of regional financial efficiency is not random, which shows that the regions with similar observed values are collectively distributed in the geographical space. 


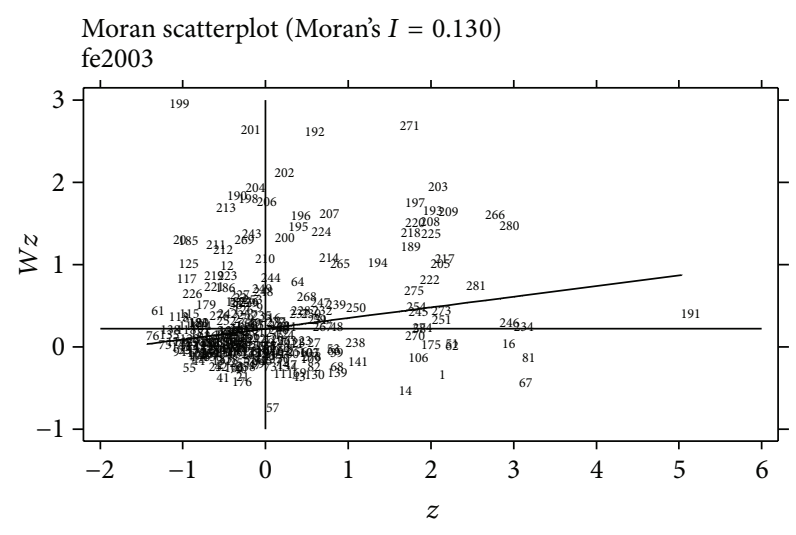

FIGURE 2: Moran's $I$ index scatter diagram of financial efficiency in 2003.

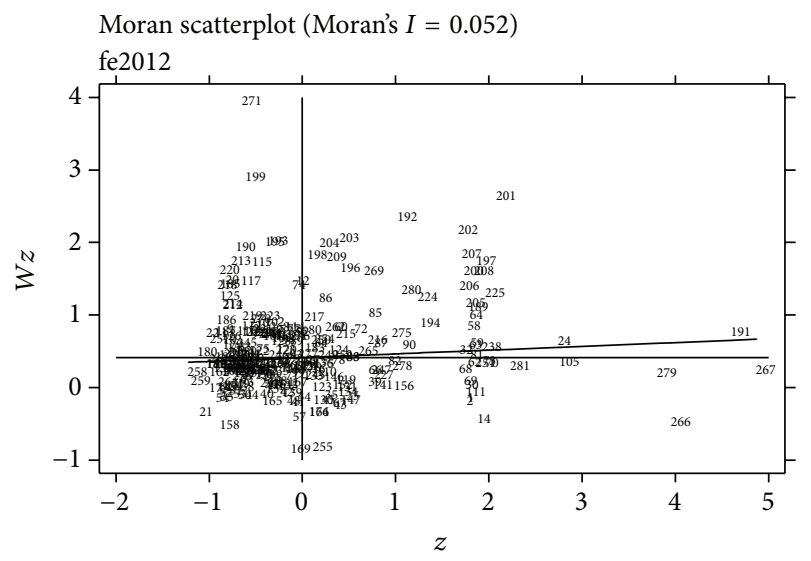

Figure 3: Moran's $I$ index scatter diagram of financial efficiency in 2012.

Namely, it presents a spatial correlation structure that the regions with high financial efficiency are inclined to be adjacent to other high-efficiency regions, while the regions with low efficiency are inclined to be adjacent to other lowefficiency regions.

In order to depict the clustering pattern of regional financial efficiency more intuitively, we will draw Moran's $I$ index scatter diagrams of regional financial efficiency in two typical years, namely, 2003 and 2012, with the use of the economic-geographical mixed weighting matrix.

Moran's $I$ index scatter diagrams divide financial efficiency clustering distribution into four quadrants, of which the first quadrant ( $\mathrm{HH}$ : high efficiency-high spatial lag) and third quadrant (LL: low efficiency-low spatial lag) reflect positive spatial correlation, and the second quadrant (LH: low efficiency-high spatial lag) and fourth quadrant (HL: high efficiency-low spatial lag) reflect negative spatial correlation. As shown in Figures 2 and 3, most regions are in the first quadrant and the third quadrant, which further confirmed that there exists significant positive spatial correlation between regional financial efficiency.

\section{Model Specification}

In order to investigate how the fiscal decentralization influences the financial efficiency and strategic competition among regional financial development, econometric model is initially expressed as

$$
\mathrm{fe}_{i t}=\beta_{0}+\beta X_{i t}+\mu_{i}+v_{t}+\varepsilon_{i t} .
$$

In (4), $i$ and $t$, respectively, indicate the region $i$ and year $t, \mu_{i}$ is a regional disturbance, $\nu_{t}$ is timing disturbance, $\varepsilon_{i t}$ is the random error, fe $e_{i t}$ represents financial efficiency, and $x_{i t}$ contains fiscal expenditure decentralization, revenue decentralization, and other controlled variables.

Flowing of capital and technology across sectors and practitioners' communication and cooperation lead to obvious clustering and rivalry among regional financial development, which indicates that the financial development and efficiency in geographically neighboring regions or the regions with similar economic structure are interdependent rather than independent to some degree. Considering the fiscal decentralization system, strategic competition caused by public policy spillover and "free rider" behavior further enhance the spatial correlation of financial efficiency and financial development among regions; we find that it is necessary to introduce the interactive dependencies among regions into the spatial econometric analysis framework, to reflect the spatial spillover effects of financial development under the fiscal decentralization system by constructing a spatial econometric model.

It has been proved that there exists spatial correlation in regional financial efficiency by using Moran statistical analysis, so we can generate spatial econometric models by introducing spatial autocorrelation factors into the general regression models. According to different forms of error shock on an observation's spatial autocorrelation, spatial econometric models can be divided into the Spatial Error Model (SEM) and the Spatial Lag Model (SLM). In our research, the SEM assumes that spatial autocorrelation stems from the error shock of neighboring regions on the dependent variables and examines the effects of neighboring regions under observation, while the SLM assumes that spatial autocorrelation stems from dependent variables and examines the effects of financial efficiency in neighboring regions on local financial efficiency. According to the principles of model construction, the SEM reflects the indirect bandwagon effects caused by error terms, whereas the SLM controls the direct bandwagon effects. LeSage and Pace [32] further establish the Spatial Durbin Model (SDM) on the basis of the SEM and the SLM. The SDM includes spatial lag terms from dependent variables and independent variables to capture the spillover effects deriving from different variables.

We will construct static Spatial Durbin Model (SDM) and dynamic Spatial Durbin Model (DSDM) to investigate how fiscal decentralization affects regional financial efficiency. Meanwhile, in order to reflect the financial efficiency's possible inertia characteristics in reality, the lag item $\left(\mathrm{fe}_{i t-1}\right)$ of financial efficiency will be introduced to the independent 
variables to measure the influence of self-reinforcing mechanism. The specific models can be expressed as

$$
\begin{aligned}
\mathrm{fe}_{i t}= & \rho W_{i j} \mathrm{fe}_{i t}+\beta X_{i t}+\theta W_{i j} X_{i t}+\mu_{i}+v_{t}+\varepsilon_{i t}, \\
\mathrm{fe}_{i t}= & \varphi \mathrm{fe}_{i t-1}+\rho W_{i j} \mathrm{fe}_{i t}+\beta X_{i t}+\theta W_{i j} X_{i t}+\mu_{i}+v_{t} \\
& +\varepsilon_{i t} .
\end{aligned}
$$

In (5), $\rho$ is the spatial lag coefficient reflecting the direction and extent of how financial efficiency in the neighboring regions affects local financial efficiency and the coefficient directly reflects the degree of spatial competition in the financial efficiency. $W_{i j}$ is the spatial weight matrix of $N T \times N T, N$ is the number of cross-sectional samples (281 prefecture-level cities), and $T$ is time (2003-2012).

\section{Variables Selection and Data Sources}

4.1. Variables Definition and Measurement Methods. According to research purpose, we will focus on the relationship between fiscal decentralization (fiscal expenditure decentralization and revenue decentralization) and regional financial efficiency in the subnational cities. Other economic and social factors affecting regional financial efficiency include regional economic development, urbanization, industrial structure, information technology development, fixed asset investment, and the level of internal opening. Therefore, we will take these indexes as controlled variables and introduce them into an empirical analysis model; the detailed variable setting and measuring methods are as follows.

4.1.1. The Dependent Variable. The dependent variable is financial efficiency (fe), which is measured by the aforementioned SBM model.

4.1.2. Main Independent Variables. Fiscal expenditure decentralization and revenue decentralization are our main independent variable. When it comes to the measure method of fiscal decentralization, we mainly use research results of Guo and Jia [33] and Gong and Lei [34] for reference. The specific measure formula of fiscal expenditure decentralization (sd) is as follows:

$$
=\frac{\mathrm{PFE}_{\text {city }}}{\mathrm{PFE}_{\text {city }}+\mathrm{PFE}_{\text {province }}+\mathrm{PFE}_{\text {nation }}}\left[1-\frac{\mathrm{GDP}_{\text {city }}}{\mathrm{GDP}_{\text {nation }}}\right] .
$$

In (6), $\mathrm{PFE}_{\text {city }}, \mathrm{PFE}_{\text {province, }}$ and $\mathrm{PFE}_{\text {nation }}$, respectively, represent per capita fiscal expenditure of each city, the provincial per capita fiscal expenditure, and the national per capita fiscal expenditure. GDP city and GDP nation, respectively, represent the GDP in each city and the national GDP. $\left[1-\mathrm{GDP}_{\text {city }} / \mathrm{GDP}_{\text {nation }}\right]$ is the reduction factor for economic scale. The index has proposed the effects of population scale and economic scale. The specific measure formula of fiscal revenue decentralization (rd) is as follows:

rd

$$
=\frac{\mathrm{PFR}_{\text {city }}}{\mathrm{PFR}_{\text {city }}+\mathrm{PFR}_{\text {province }}+\mathrm{PFR}_{\text {nation }}}\left[1-\frac{\mathrm{GDP}_{\text {city }}}{\mathrm{GDP}_{\text {nation }}}\right] \text {. }
$$

In (7), $\mathrm{PFR}_{\text {city }}, \mathrm{PFR}_{\text {province, }}$ and $\mathrm{PFR}_{\text {nation }}$, respectively, represent per capita fiscal revenue of each city, the provincial per capita fiscal revenue, and the national per capita fiscal revenue. $\mathrm{GDP}_{\text {city }}$ and $\mathrm{GDP}_{\text {nation }}$, respectively, represent the GDP in each city and the national GDP.

4.1.3. Controlled Variable. Controlled variables are as follows.

(1) Regional economic development ( $p g d p)$ : regional economy provides the necessary material and nonmaterial support for the financial development and innovation; the higher the level of regional economic development is, the more beneficial to financial efficiency the improvement is. In this paper, per capita actual GDP is used as a proxy variable for regional economic development. To exclude the influence of price factor, the foregoing data that involve value are adjusted in accordance with constant 2003 prices.

(2) Urbanization (urban): Urbanization of population (the proportion of nonagricultural population accounts for total population) is used as the proxy variable, in which the data of nonagricultural population covering the period from 2003 to 2008 is from "China Urban Statistical Yearbook" (2004-2009), and the data of nonagricultural population covering the period from 2009 to 2012 is from the annual "Statistics on Population of Counties and Cities in China".

(3) Industrial structure (itu): the upgrading and adjustment of regional industrial structure constitutes a soft environment for financial development and innovation. The higher the proportion of the third industry is, the more beneficial to financial efficiency the improvement is. In this paper, the index of industrial structure upgrading is used to represent industrial structure and the specific measure formula is as follows:

$$
\mathrm{itu}=\sum_{j=1}^{n} q(j) * j .
$$

In (8) $q(j)$ is the proportion of the third industry accounts for local GDP in region $j, n=3$, and the value of index ranges from 1 to 3 .

(4) Information technology development (internet): it is measured by the number of internet users in each city.

(5) Fixed asset investment (ifa): it is measured by the actual fixed asset investment in each city.

(6) The level of internal opening (private): with reference to the research result of Fan et al. [35], we use the development of private enterprises to measure the level of internal opening and assume that the higher the level of the development of private enterprise is, the stronger the flexibility of local financial innovation activities is, which is more conducive to financial efficiency improvement. The proportion of the employees of private enterprises and self-employed employees account for the local total population is used as a proxy to 
measure the development of private enterprises in different regions.

4.1.4. Spatial Weight Matrixes. Strategic competition tends to occur in the regions with the similar level of economic development; simultaneously the concentration effect will gradually decay with the geographical distance [36]. In order to comprehensively reflect the spatial effects of geographical and economic characteristics and accurately measure the spatial correlation among regions, we will construct the mixed geography-economy weighting matrix. The specific measure formula is as follows:

$$
W_{\text {eco-geo }}= \begin{cases}\frac{\left|\bar{Q}_{i}-\bar{Q}_{j}\right|}{d_{i j}{ }^{2}} & i \neq j \\ 0 & i=j .\end{cases}
$$

In (9), $W_{\text {eco-geo }}$ is mixed geography-economy weighting matrix, $\bar{Q}_{i}$ and $\bar{Q}_{j}$, respectively, represent the per capita actual GDP of city $i$ and city $j$ (the mean of the actual GDP covering the period from 2003 to 2012), and $d_{i j}$ is the geographical distance between city $i$ and city $j$ calculated with the latitude and longitude data of prefecture-level city's administrative unit. The specific measure formula is as follows:

$$
\begin{aligned}
d_{i j} & =R \arccos \left(\sin \varphi_{A} \sin \varphi_{B}\right. \\
& \left.+\cos \varphi_{A} \cos \varphi_{B} \cos \left(\lambda_{B}-\lambda_{A}\right)\right) .
\end{aligned}
$$

In (10), $R$ is the earth circle radius $(6378 \mathrm{~km})$ and $\lambda$ and $\varphi$, respectively, represent administrative center's longitude and latitude of city $i$ and city $j$. Longitude and latitude data are from the national fundamental geographic information system. All of the diagonal elements of matrix $W_{\text {eco-geo }}$ are 0 . And the weight matrix is normalized so that the sum of line elements is 1 . In addition, considering the reliability and robustness of statistical analysis, we will also construct geographical distance weight matrix to make a spatial econometric analysis and then compare the corresponding estimated results. The specific measure formula of geographical distance weight matrix is as follows:

$$
W_{\text {geo }}= \begin{cases}\frac{1}{d_{i j}^{2}} & i \neq j \\ 0 & i=j .\end{cases}
$$

In (11), $W_{\text {geo }}$ is a geographical distance weighting matrix, which is also normalized so that the sum of line elements is 1 , and other indexes are consistent with that of (10).

4.2. Data Sources and Description. Considering the availability of data and consistency of research samples, we eventually choose 281 prefecture-level cities (Hong Kong, Macao, and Taiwan are excluded) as samples and exclude Bazhong, Ziyang, Lhasa, Jinchang, Baiyin, Zhongwei, and other cities due to a serious lack of available data. The research period is covering the period from 2003 to 2012, and the data is from "China City Statistical Yearbook," "Regional
Economic China Statistical Yearbook," and provincial statistical yearbooks covering the period from 2004 to 2013. The missing data was partially filled by interpolation. In order to weaken the influence of heteroskedasticity, outliers and anomaly terms on the data stability, all the data are processed by the logarithm. An overview of the descriptive statistics of these data is provided in Table 2.

In order to avoid the deviation of the model setting and spurious regression, we carry on unit root testing on related variables by LLC and Fisher-ADF testing methods before spatial econometric regression analysis. The results of stationary testing of panel data indicate that all variables reject the null hypothesis of unit root, which passes the test at the 5\% significance level. Moreover, the panel data are stationary, and the regression results will be significantly reliable.

\section{Empirical Methodology}

5.1. Spatial Econometric Analysis of Fiscal Decentralization on Regional Financial Efficiency. Since the SDM model contains the spatial lag item of the dependent variable and the spatial lag items of independent variables at the same time, so it can more fully reflect the impact of spatial autocorrelation on the regression results than SEM model and SLM model [32]. Therefore, we construct SDM models to test the spatial effects of the fiscal revenue decentralization and fiscal expenditure decentralization on the regional financial efficiency. The $P$ values of Hausman test of the spatial econometric models are less than 0.05 , which indicates that the estimated results of fixed effect estimation are better than that of random effect estimation. Therefore, we will specifically carry out analysis according to the estimated results of spatially fixed effect models in the following parts. Meanwhile, a robust test is carried by constructing DSDM models. It is found that the estimated coefficients of SDM model and DSDM model have the same direction, while the values of estimated coefficients and level of significance are also very close, indicating that the results of SDM model are significantly reliable. Comparing the values of $R^{2}$ and Log-likelihood of SDM model and DSDM model, we find that the fitting degree of SDM model is higher than that of DSDM model, so the following analysis is mainly based on the econometric results of SDM model.

As shown in Table 3, the overall spatial correlation coefficients $\rho$ of four models are positive and pass the tests at the $1 \%$ significance level, indicating that there are positive spatial dependent relationships between the local financial efficiency and the neighboring regions' financial efficiency; that is, the economic activities of geography neighborhood regions or regions with similar level of economic development have obvious spillover effect on local financial efficiency, thereby causing imitation and strategic competition of financial development and innovation among regions. On one hand, the geographical adjacency and similarity of economic development in different regions bring huge convenience to cooperation between financial enterprises, sharing of infrastructure, information exchange and communication, innovation and diffusion of knowledge 
TABLE 2: Statistical description of sample’s variables.

\begin{tabular}{|c|c|c|c|c|c|c|c|c|}
\hline Index & Variables & Mean & $\begin{array}{l}\text { Standard } \\
\text { deviation }\end{array}$ & Minimum & $25 \%$ quantile & $50 \%$ quantile & $75 \%$ quantile & Maximum \\
\hline Finance efficiency & $\mathrm{fe}$ & 0.576 & 0.624 & 0.133 & 0.380 & 0.500 & 0.653 & 3.958 \\
\hline $\begin{array}{l}\text { Fiscal expenditure } \\
\text { decentralization }\end{array}$ & sd & 0.368 & 0.108 & 0.138 & 0.294 & 0.351 & 0.421 & 0.888 \\
\hline $\begin{array}{l}\text { Fiscal revenue } \\
\text { decentralization }\end{array}$ & rd & 0.242 & 0.146 & 0.037 & 0.133 & 0.202 & 0.318 & 0.871 \\
\hline $\begin{array}{l}\text { Per capita real GDP } \\
\text { (yuan/person) }\end{array}$ & pgdp & $2.7 e+04$ & $3.2 e+04$ & 1891.200 & 9837.380 & $1.7 e+04$ & $3.1 e+04$ & $4.4 e+05$ \\
\hline Urbanization (\%) & Urban & 0.345 & 0.195 & 0.013 & 0.202 & 0.296 & 0.451 & 100.000 \\
\hline Industrial structure & itu & 2.203 & 0.136 & 1.318 & 2.110 & 2.190 & 2.283 & 2.797 \\
\hline $\begin{array}{l}\text { Information } \\
\text { technology } \\
\text { development (ten } \\
\text { thousand families) }\end{array}$ & Internet & 41.066 & 128.506 & 0.024 & 8.316 & 17.139 & 36.800 & 5174.000 \\
\hline $\begin{array}{l}\text { Fixed asset } \\
\text { investment (ten } \\
\text { thousand yuan) }\end{array}$ & ifa & $1.5 e+04$ & $1.5 e+04$ & 654.299 & 4606.420 & 9841.960 & $2.0 e+04$ & $1.7 e+05$ \\
\hline $\begin{array}{l}\text { The level of internal } \\
\text { opening (\%) }\end{array}$ & Private & 0.086 & 0.106 & 0.003 & 0.036 & 0.059 & 0.096 & 100.000 \\
\hline
\end{tabular}

and technology, flowing of financial resources among regions, which causes regional financial development and innovation, and imitation and strategic competition among regions [37]; on the other hand, the restriction of transportation cost on financial sector is not strong and the rapid development of internet technology leads to cross-regional financial transactions and innovation, thus further expanding the clustering effect, effect of economic scale, and spatial spillover effects of financial development. The coefficients of lag item $\left(\mathrm{fe}_{i t-1}\right)$ of financial efficiency in DSDM models are positive, and they are, respectively, 0.211 and 0.212 ; both of them pass the tests at the $1 \%$ significance level, indicating that the previous inputs and outputs of production will be present through the financial efficiency increasing in later stage (or later period), and financial efficiency increasing is a dynamic systemic process. The specific impact of each variable on financial efficiency is analyzed as follows.

The estimated coefficients of Lnsd and Lnrd are positive, and all of them pass the tests at the $1 \%$ significance level, which indicates that the fiscal expenditure and revenue decentralization play a significant positive role in promoting local financial efficiency. Under the dual pressures of making up the fiscal gap and political promotion, the local governments regarding economic development as main mission have instinctive strong interest in scarce flowing economic factors [38]. As the excellent combination of capital, talent, technology, management, and marketing, financial resources will be the important target for battling among local governments. With the expansion of fiscal expenditure decentralization and revenue decentralization, local government uses many policy tools such as fiscal subsidies, tax concessions, and government procurement to compete for getting the financial resources by attracting financial capital, human capital, and technological innovation to flow into the local region, thus contributing to the financial innovation and improvement of financial efficiency. The influence coefficient of fiscal expenditure decentralization is 0.357 , greater than the influence coefficient (0.153) of fiscal revenue decentralization, indicating that the impacts of fiscal expenditure decentralization and revenue decentralization on regional financial efficiency have unbalanced characteristics, and the possible reason is that local governments under province get very limited taxation autonomy, resulting in the fact that revenue decentralization is often lower than expenditure decentralization. In addition, under the capital-driven economic growth model, the flowing direction of capital depends on the level of infrastructure [39]; thus the inflow of financial resources as well as financial innovation often occurs in the regions with rapid economic development, excellent investment environment, and great consumption ability, so that local governments have to increase fiscal expenditure to enhance the supply of the associated supporting infrastructure. Comparatively speaking, tax preference of undeveloped regions is less attractive than the superiority conditions of developed regions.

We will further analyze the estimated coefficients and significance levels of spatial lags of fiscal expenditure and revenue decentralization and investigate the strategic competitive effects of financial efficiency among neighboring regions. The spatial lag of expenditure decentralization (WLnsd) does not pass the significance test, suggesting that spatial spillover effect of fiscal expenditure decentralization is uncertain and needs further examination, while the spatial lag of fiscal revenue decentralization (WLnrd) is negative at the $5 \%$ significance level, and the estimated coefficient is -0.228 , indicating that, with the increase of fiscal revenue decentralization, the negative externalities on financial development and innovation will be increasingly prominent, thus inhibiting the improvement of financial efficiency in neighboring regions. The reason may be that 
TABLE 3: Estimated results of regional financial efficiency under the Spatial Durbin Model (economic-geographic weighting matrix).

\begin{tabular}{|c|c|c|c|c|}
\hline \multirow{2}{*}{$\begin{array}{l}\text { Independent } \\
\text { variables }\end{array}$} & \multicolumn{2}{|c|}{ Dependent variable: sd } & \multicolumn{2}{|c|}{ Dependent variable: rd } \\
\hline & SDM model & $\begin{array}{l}\text { DSDM } \\
\text { model }\end{array}$ & SDM model & $\begin{array}{c}\text { DSDM } \\
\text { model }\end{array}$ \\
\hline $\mathrm{fe}_{i t-1}$ & & $\begin{array}{c}0.211^{* * *} \\
(12.83)\end{array}$ & & $\begin{array}{c}0.212^{* * *} \\
(12.83)\end{array}$ \\
\hline Lnsd & $\begin{array}{c}0.357^{* * *} \\
(6.26)\end{array}$ & $\begin{array}{c}0.334^{* * *} \\
\quad(5.70)\end{array}$ & & \\
\hline Lnrd & & & $\begin{array}{c}0.153^{* * *} \\
(4.70)\end{array}$ & $\begin{array}{c}0.143^{* * *} \\
(4.08)\end{array}$ \\
\hline Lnpgdp & $\begin{array}{c}0.169^{* * *} \\
(4.62)\end{array}$ & $\begin{array}{c}0.120^{* * *} \\
(3.08)\end{array}$ & $\begin{array}{c}0.138^{* * *} \\
(3.60)\end{array}$ & $\begin{array}{c}0.099^{* *} \\
(2.44)\end{array}$ \\
\hline Lnurban & $\begin{array}{c}-0.050^{* *} \\
(-2.37)\end{array}$ & $\begin{array}{c}-0.044^{* *} \\
(-2.09)\end{array}$ & $\begin{array}{c}-0.050^{* *} \\
(-2.37)\end{array}$ & $\begin{array}{c}-0.045^{* *} \\
(-2.15)\end{array}$ \\
\hline Lnitu & $\begin{array}{c}0.433^{* *} \\
(2.27)\end{array}$ & $\begin{array}{c}0.438^{* *} \\
(2.15)\end{array}$ & $\begin{array}{c}0.525^{* * *} \\
(2.73)\end{array}$ & $\begin{array}{c}0.531^{* * *} \\
(2.59)\end{array}$ \\
\hline Lninternet & $\begin{array}{c}-0.295^{* * *} \\
(-29.70)\end{array}$ & $\begin{array}{c}-0.299^{* * *} \\
(-27.16)\end{array}$ & $\begin{array}{c}-0.292^{* * *} \\
(-29.45)\end{array}$ & $\begin{array}{c}-0.297^{* * *} \\
(-26.90)\end{array}$ \\
\hline Lnifa & $\begin{array}{c}-0.446^{* * *} \\
(-22.98)\end{array}$ & $\begin{array}{c}-0.386^{* * *} \\
(-18.32)\end{array}$ & $\begin{array}{c}-0.437^{* * *} \\
(-23.21)\end{array}$ & $\begin{array}{r}-0.374^{* * *} \\
(-18.06)\end{array}$ \\
\hline Lnprivate & $\begin{array}{c}0.038^{* * *} \\
(3.22)\end{array}$ & $\begin{array}{c}0.037^{* * *} \\
(2.90)\end{array}$ & $\begin{array}{c}0.039^{* * *} \\
(3.25)\end{array}$ & $\begin{array}{c}0.038^{* * *} \\
(3.02)\end{array}$ \\
\hline WLnsd & $\begin{array}{c}0.179 \\
(0.99)\end{array}$ & $\begin{array}{l}-0.041 \\
(-0.22)\end{array}$ & & \\
\hline WLnrd & & & $\begin{array}{c}-0.228^{* *} \\
(-2.51)\end{array}$ & $\begin{array}{c}-0.186^{*} \\
(-1.79)\end{array}$ \\
\hline WLnpgdp & $\begin{array}{l}0.016 \\
(0.27)\end{array}$ & $\begin{array}{r}0.064 \\
(1.01)\end{array}$ & $\begin{array}{l}0.058 \\
(0.96)\end{array}$ & $\begin{array}{l}0.097 \\
(1.50)\end{array}$ \\
\hline WLnurban & $\begin{array}{c}0.097^{* *} \\
(2.36)\end{array}$ & $\begin{array}{c}0.082^{* *} \\
(1.98)\end{array}$ & $\begin{array}{c}0.107^{* * *} \\
(2.59)\end{array}$ & $\begin{array}{c}0.089^{* *} \\
(2.13)\end{array}$ \\
\hline WLnitu & $\begin{array}{c}1.159^{*} \\
(1.93)\end{array}$ & $\begin{array}{l}0.516 \\
(0.82)\end{array}$ & $\begin{array}{l}0.615 \\
(1.00)\end{array}$ & $\begin{array}{l}0.228 \\
(0.35)\end{array}$ \\
\hline WLninternet & $\begin{array}{c}0.177^{* * *} \\
(6.47)\end{array}$ & $\begin{array}{c}0.181^{* * *} \\
(6.22)\end{array}$ & $\begin{array}{c}0.180^{* * *} \\
(6.66)\end{array}$ & $\begin{array}{c}0.180^{* * *} \\
(6.19)\end{array}$ \\
\hline WLnifa & $\begin{array}{c}0.237^{* * *} \\
\quad(5.39)\end{array}$ & $\begin{array}{l}0.251^{* * *} \\
\quad(5.32)\end{array}$ & $\begin{array}{c}0.275^{* * *} \\
(7.04)\end{array}$ & $\begin{array}{c}0.260^{* * *} \\
(6.00)\end{array}$ \\
\hline WLnprivate & $\begin{array}{c}0.065^{*} \\
(1.85)\end{array}$ & $\begin{array}{r}0.045 \\
(1.15)\end{array}$ & $\begin{array}{c}0.083^{* *} \\
(2.32)\end{array}$ & $\begin{array}{l}0.060 \\
(1.53)\end{array}$ \\
\hline$\rho$ & $\begin{array}{c}0.420^{* * *} \\
(11.65)\end{array}$ & $\begin{array}{c}0.462^{* * *} \\
(12.51)\end{array}$ & $\begin{array}{c}0.429^{* * *} \\
(12.05)\end{array}$ & $\begin{array}{c}0.463^{* * *} \\
(12.66)\end{array}$ \\
\hline$R^{2}$ & 0.448 & 0.443 & 0.441 & 0.438 \\
\hline $\log L$ & 599.812 & 595.228 & 595.228 & 587.624 \\
\hline Observations & 2810 & 2529 & 2810 & 2529 \\
\hline
\end{tabular}

Note: the values in parentheses represent the $t$-statistics values of the corresponding estimated coefficients. $* * *, * *$, and $*$, respectively represent significance level of $1 \%, 5 \%$, and $10 \%$.

local governments' motivation of pursuing revenues under the fiscal revenue decentralization system is not conducive to free flowing of financial resources among regions, which directly affects the financial efficiency in other regions.

When it comes to the estimated coefficients of other controlled variables, we found that not all the spatial spillover effects of variables are significant. Overall, various economic activities have direct and indirect influence on financial efficiency and promote the strategic financial competition among regions. The specific effects are as follows: the level of open-into-inside can not only improve the local financial efficiency significantly, but also increase the financial efficiency correspondingly in neighboring regions. The strong demand for various financial products and services of private enterprises promotes financial innovation and improves the efficiency of resource allocation in financial markets. On the contrary, urbanization, information technology development, and fixed assets investment suppress the improvement of local financial efficiency but play a positive role in promoting the financial efficiency in neighboring regions. The accelerating of urbanization process, the application of internet technology, and investment in fixed assets promote economic exchanges and cooperation among regions, so that the spatial spillover effects of financial development and innovation are increasingly significant. Furthermore, although the regional economic development and industrial structure significantly contribute to the improvement of regional financial efficiency in general, the spillover effects among regions are not obvious.

5.2. Decomposition of Fiscal Decentralization's Effects on Regional Financial Efficiency. Whether there truly exist spillover effects among the variables, relying solely on the spatial lag coefficients of SDM model and DSDM model, is likely to lead to misinterpretation of the estimated results. Spatial effects can be further decomposed into direct effect, indirect effect (spillover effects), and total effect with reference to the research result of LeSage and Pace [32]. The indirect effects represent the independent variables' influence on the dependent variable in all other regions through spatial interactions. Therefore, we will further verify the existence of spillover effects by using partial differential matrix analysis. Table 4 illustrates the direct effect, indirect effect, and total effect of the fiscal expenditure and revenue decentralization in SDM model. The results show that the estimated coefficients of independent variables' direct effect have the same direction with the estimated coefficients of SDM model in Table 3, and the estimated coefficients and significance levels are also very close.

According to the estimated results of SDM model in Table 4, the direct effect, indirect effect, and total effect of fiscal expenditure decentralization on regional financial efficiency are positive and pass the $10 \%$ significance level test. The regression coefficient of direct effect is 0.368 , the regression coefficient of indirect effect is 0.560 , and the regression coefficient of total effect is 0.928 , indicating that the degree of fiscal expenditure decentralization increases by $1 \%$, while regional financial efficiency increases by $0.928 \%$. Fiscal expenditure decentralization plays a significant positive impact on financial development and financial efficiency, which is opposite to the research result of Wang and Li [23]. The opposite conclusions are possibly due to the differences of sample selection and indexes. The rise of fiscal expenditure decentralization in the local region leads to an increase by $0.368 \%$ of the financial efficiency, while the increase of expenditure decentralization in the neighboring region leads to financial efficiency increasing by $0.560 \%$, indicating that 
TABLE 4: Decomposition of direct effect, indirect effect, and total effect under SDM model.

\begin{tabular}{|c|c|c|c|c|c|c|}
\hline \multirow{2}{*}{ Independent variables } & \multicolumn{3}{|c|}{ Dependent variable: sd } & \multicolumn{3}{|c|}{ Dependent variable: sd } \\
\hline & Direct effect & Indirect effect & Total effect & Direct effect & Indirect effect & Total effect \\
\hline Lnsd & $\begin{array}{c}0.368^{* * *} \\
(7.50)\end{array}$ & $\begin{array}{r}0.560^{*} \\
(1.95)\end{array}$ & $\begin{array}{c}0.928^{* * *} \\
(3.10)\end{array}$ & & & \\
\hline Lnrd & & & & $\begin{array}{c}0.146^{* * *} \\
(5.29)\end{array}$ & $\begin{array}{c}-0.283^{*} \\
(-1.95)\end{array}$ & $\begin{array}{c}-0.137^{*} \\
(-1.92)\end{array}$ \\
\hline Lnpgdp & $\begin{array}{c}0.175^{* * *} \\
(4.35)\end{array}$ & $\begin{array}{l}0.132 \\
(1.53)\end{array}$ & $\begin{array}{c}0.307^{* * *} \\
(3.59)\end{array}$ & $\begin{array}{c}0.145^{* * *} \\
(3.46)\end{array}$ & $\begin{array}{c}0.187^{* *} \\
(2.18)\end{array}$ & $\begin{array}{c}0.332^{* * *} \\
(3.92)\end{array}$ \\
\hline Lnurban & $\begin{array}{c}-0.046^{* *} \\
(-2.07)\end{array}$ & $\begin{array}{r}0.127^{* *} \\
(2.00)\end{array}$ & $\begin{array}{l}0.081 \\
(1.30)\end{array}$ & $\begin{array}{c}-0.045^{* *} \\
(-2.04)\end{array}$ & $\begin{array}{c}0.146^{* *} \\
(2.26)\end{array}$ & $\begin{array}{l}0.101 \\
(1.58)\end{array}$ \\
\hline Lnitu & $\begin{array}{c}0.486^{* * *} \\
(2.75)\end{array}$ & $\begin{array}{r}2.321^{* *} \\
(2.37)\end{array}$ & $\begin{array}{c}2.807^{* * *} \\
(2.92)\end{array}$ & $\begin{array}{c}0.559^{* * *} \\
(3.15)\end{array}$ & $\begin{array}{l}1.488 \\
(1.51)\end{array}$ & $\begin{array}{c}2.047^{* *} \\
(2.11)\end{array}$ \\
\hline Lninternet & $\begin{array}{c}-0.291^{* * *} \\
(-30.55)\end{array}$ & $\begin{array}{r}0.086^{*} \\
(1.90)\end{array}$ & $\begin{array}{c}-0.205^{* * *} \\
(-4.32)\end{array}$ & $\begin{array}{c}-0.288^{* * *} \\
(-30.29)\end{array}$ & $\begin{array}{c}0.091^{* *} \\
(2.00)\end{array}$ & $\begin{array}{c}-0.197^{* * *} \\
(-4.10)\end{array}$ \\
\hline Lnifa & $\begin{array}{c}-0.441^{* * *} \\
(-22.60)\end{array}$ & $\begin{array}{l}0.087 \\
(1.49)\end{array}$ & $\begin{array}{c}-0.353^{* * *} \\
(-5.94)\end{array}$ & $\begin{array}{c}-0.430^{* * *} \\
(-22.54)\end{array}$ & $\begin{array}{c}0.154^{* * *} \\
(2.83)\end{array}$ & $\begin{array}{c}-0.276^{* * *} \\
(-4.94)\end{array}$ \\
\hline Lnprivate & $\begin{array}{c}0.041^{* * *} \\
(3.19)\end{array}$ & $\begin{array}{c}0.134^{* *} \\
(2.35) \\
\end{array}$ & $\begin{array}{c}0.175^{* * *} \\
(2.85) \\
\end{array}$ & $\begin{array}{c}0.042^{* * *} \\
(3.27)\end{array}$ & $\begin{array}{c}0.166^{* * *} \\
(2.83)\end{array}$ & $\begin{array}{c}0.208^{* * *} \\
(3.30)\end{array}$ \\
\hline
\end{tabular}

Note: $* * *, * *$, and $*$, respectively, represent the significant level of $1 \%, 5 \%$, and $10 \%$.

fiscal expenditure decentralization significantly promotes the competition of financial development and innovation among regions. The expansion of the autonomy of local government expenditure strengthens the regulatory capacity of local governments, which is conducive to accelerating market-oriented reform processing, and achieves the organic integration between fiscal system and market mechanism in the allocation of financial resources, which is beneficial to creating a favorable institutional environment, is also conducive to the flowing of financial resources among regions, and greatly promotes financial efficiency.

The fiscal revenue decentralization's direct effect on regional financial efficiency is significantly positive, while the spillover effect is significantly negative, indicating that the impact of fiscal revenue decentralization on regional financial efficiency presents the feature of "double-edgedsword." Fiscal revenue decentralization has a significant positive impact on the local financial efficiency. However there are significant negative spillover effects on the financial efficiency in other regions. The regression coefficient of the direct effect is 0.146 , the regression coefficient of the indirect effect is -0.283 , and the regression coefficient of the total effect is -0.137 , which indicates that the degree of fiscal revenue decentralization increasing by $1 \%$ will lead to decrease by $0.137 \%$ of regional financial efficiency. Furthermore, while the increase of local fiscal revenue decentralization leads to financial efficiency's increase by $0.146 \%$, the increase of the fiscal revenue decentralization in neighboring regions results in the financial efficiency's decrease by $0.283 \%$. Comparing the estimated coefficient of direct effect and that of indirect effect, it can be found that the negative spillover effects of fiscal revenue decentralization are significantly greater than the direct scale effect, so the negative externalities of fiscal revenue decentralization on financial efficiency are greater than the positive externality. On one hand, in order to obtain high-quality financial resources, the local governments ignore the differences like the level of economic development, factor endowments, and other aspects among regions and seek to imitate policies and instruments in other regions, thus leading to chain reaction of absorbing investment by other regions. On the other hand, when the neighboring regions or the regions with similar level of economic development take some measures to attract liquidity factors, the local government driven by yardstick competition will adopt similar policies to avoid the outflow of elements, which results in convergence of competitive tactics [40, 41]. Tax incentives, reduction of fee, and other ways will become important means of competition and imitation between local governments in different regions on the basis of the independent revenue authority. However, such kind of competitive mode between local governments for resources will consume huge fiscal resources and weaken the capacity of local government's provision of public goods and services. Ultimately, it is harmful to provide healthy, stable, and sustainable economic development environment for financial innovation and increase of financial efficiency.

5.3. Robustness Test. To ensure the robustness and reliability of research results, we will calculate the spatial lags with the geographical distance weight matrix and do econometric regression by taking financial efficiency as the dependent variable, so that we can comparatively analyze the difference of influence with different spatial weight setting based on the above. The robustness test results are as in Table 5 .

As shown in Table 5, the estimated results indicate that the sign of regression coefficients of the fiscal expenditure decentralization and revenue decentralization is consistent with that of corresponding variable in the model of Table 3, and the regression results in the model are basically consistent with the conclusions in Table 3. Comparing the estimated results based on two different weight matrixes, it is found that there are some differences in the influence coefficients of two 
TABle 5: Robustness test on Spatial Durbin Models (geographical distance weight matrix).

\begin{tabular}{|c|c|c|c|c|}
\hline \multirow{2}{*}{$\begin{array}{l}\text { Independent } \\
\text { variables }\end{array}$} & \multicolumn{2}{|c|}{ Dependent variable: sd } & \multicolumn{2}{|c|}{ Dependent variable: rd } \\
\hline & $\begin{array}{l}\text { SDM } \\
\text { model }\end{array}$ & $\begin{array}{l}\text { DSDM } \\
\text { model }\end{array}$ & $\begin{array}{l}\text { SDM } \\
\text { model }\end{array}$ & $\begin{array}{l}\text { DSDM } \\
\text { model }\end{array}$ \\
\hline $\mathrm{fe}_{i t-1}$ & - & $\begin{array}{c}0.202^{* * *} \\
(12.76)\end{array}$ & - & $\begin{array}{c}0.200^{* * *} \\
(12.55)\end{array}$ \\
\hline Lnsd or Lnrd & $\begin{array}{c}0.364^{* * *} \\
(6.36)\end{array}$ & $\begin{array}{c}0.348^{* * *} \\
\quad(5.92)\end{array}$ & $\begin{array}{c}0.173^{* * *} \\
(5.22)\end{array}$ & $\begin{array}{c}0.161^{* * *} \\
(4.58)\end{array}$ \\
\hline Lnpgdp & $\begin{array}{c}0.268^{* * *} \\
(7.35)\end{array}$ & $\begin{array}{c}0.225^{* * *} \\
(5.78)\end{array}$ & $\begin{array}{c}0.242^{* * *} \\
(6.37)\end{array}$ & $\begin{array}{c}0.209^{* * *} \\
(5.22)\end{array}$ \\
\hline Lnurban & $\begin{array}{l}-0.026 \\
(-1.12)\end{array}$ & $\begin{array}{r}-0.026 \\
(-1.12)\end{array}$ & $\begin{array}{l}-0.028 \\
(-1.20)\end{array}$ & $\begin{array}{l}-0.027 \\
(-1.15)\end{array}$ \\
\hline Lnitu & $\begin{array}{c}0.465^{* *} \\
(2.46)\end{array}$ & $\begin{array}{c}0.478^{* *} \\
(2.38)\end{array}$ & $\begin{array}{c}0.527^{* * *} \\
(2.78)\end{array}$ & $\begin{array}{c}0.542^{* * *} \\
(2.69)\end{array}$ \\
\hline Lninternet & $\begin{array}{c}-0.295^{* * *} \\
(-30.38)\end{array}$ & $\begin{array}{c}-0.300^{* * *} \\
(-27.99)\end{array}$ & $\begin{array}{c}-0.292^{* * *} \\
(-30.05)\end{array}$ & $\begin{array}{c}-0.298^{* * *} \\
(-27.71)\end{array}$ \\
\hline Lnifa & $\begin{array}{c}-0.484^{* * *} \\
(-24.79)\end{array}$ & $\begin{array}{c}-0.427^{* * *} \\
(-20.24)\end{array}$ & $\begin{array}{c}-0.472^{* * *} \\
(-24.48)\end{array}$ & $\begin{array}{c}-0.417^{* * *} \\
(-19.88)\end{array}$ \\
\hline Lnprivate & $\begin{array}{c}0.036^{* * *} \\
(3.12)\end{array}$ & $\begin{array}{c}0.035^{* * *} \\
(2.84)\end{array}$ & $\begin{array}{c}0.035^{* * *} \\
(3.07)\end{array}$ & $\begin{array}{c}0.035^{* * *} \\
(2.88)\end{array}$ \\
\hline $\begin{array}{l}\text { WLnsd or } \\
\text { WLnrd }\end{array}$ & $\begin{array}{c}-0.264 \\
(-1.49)\end{array}$ & $\begin{array}{c}-0.418^{* *} \\
(-2.25)\end{array}$ & $\begin{array}{c}-0.277^{* * *} \\
(-3.70)\end{array}$ & $\begin{array}{c}-0.241^{* * *} \\
(-2.76)\end{array}$ \\
\hline WLnpgdp & $\begin{array}{c}-0.269^{* * *} \\
(-4.27)\end{array}$ & $\begin{array}{c}-0.286^{* * *} \\
(-4.28)\end{array}$ & $\begin{array}{c}-0.237^{* * *} \\
(-3.69)\end{array}$ & $\begin{array}{c}-0.267^{* * *} \\
(-3.94)\end{array}$ \\
\hline WLnurban & $\begin{array}{l}0.053 \\
(1.47)\end{array}$ & $\begin{array}{c}0.059^{*} \\
(1.67)\end{array}$ & $\begin{array}{l}0.059 \\
(1.63)\end{array}$ & $\begin{array}{c}0.062^{*} \\
(1.73)\end{array}$ \\
\hline WLnitu & $\begin{array}{l}0.104 \\
(0.20)\end{array}$ & $\begin{array}{l}-0.085 \\
(-0.16)\end{array}$ & $\begin{array}{l}-0.205 \\
(-0.39)\end{array}$ & $\begin{array}{l}-0.290 \\
(-0.51)\end{array}$ \\
\hline WLninternet & $\begin{array}{c}0.217^{* * *} \\
(8.38)\end{array}$ & $\begin{array}{c}0.239^{* * *} \\
(8.53)\end{array}$ & $\begin{array}{c}0.214^{* * *} \\
(8.31)\end{array}$ & $\begin{array}{c}0.235^{* * *} \\
(8.41)\end{array}$ \\
\hline WLnifa & $\begin{array}{c}0.434^{* * *} \\
(10.52)\end{array}$ & $\begin{array}{c}0.464^{* * *} \\
(10.54)\end{array}$ & $\begin{array}{c}0.433^{* * *} \\
(11.65)\end{array}$ & $\begin{array}{c}0.450^{* * *} \\
(11.29)\end{array}$ \\
\hline WLnprivate & $\begin{array}{c}0.062^{*} \\
(1.87)\end{array}$ & $\begin{array}{l}0.038 \\
(1.06)\end{array}$ & $\begin{array}{c}0.081^{* *} \\
(2.41)\end{array}$ & $\begin{array}{l}0.050 \\
(1.39)\end{array}$ \\
\hline$\rho$ & $\begin{array}{c}0.547^{* * *} \\
(18.58)\end{array}$ & $\begin{array}{c}0.580^{* * *} \\
(19.38)\end{array}$ & $\begin{array}{c}0.541^{* * *} \\
(18.39)\end{array}$ & $\begin{array}{c}0.570^{* * *} \\
(18.98)\end{array}$ \\
\hline$R^{2}$ & 0.444 & 0.428 & 0.443 & 0.430 \\
\hline $\log L$ & 659.741 & 665.804 & 665.804 & 659.509 \\
\hline Observations & 2810 & 2529 & 2810 & 2529 \\
\hline
\end{tabular}

Note: $* * *, * *$, and $*$, respectively, represent the significant level of $1 \%, 5 \%$, and $10 \%$.

kinds of fiscal decentralizations indicators, which show that the gap between the levels of economic development will have an impact on role of fiscal decentralization acting on regional financial efficiency. On one hand, under the fiscal decentralization system, because of the heterogeneity of regional economic development level, the local governments' ability of making up the gap between fiscal revenue and expenditure is different, and the fiscal pressure is also different; therefore the degree of interference to the regional market environment by the local government is different, which leads to the regional differences in financial efficiency in a certain degree [21]. On the other hand, the occurrence of financial innovation depends on the support of the economic foundation, and the different economic and social environment will lead to the fact that the financial innovation activities are more and more concentrated in the regions with the advantages of financial location, resulting in nonequilibrium of financial efficiency in different regions [42]. Under the performance assessment method focusing on GDP, local governments will not only consider the strategic behaviors of the neighboring regions but also tend to think about the behaviors of the regions with the similar level of economy. In addition, cross-regional knowledge diffusion, technology spillover, and human capital flow are more prone to occur among the regions with similar level of economic development, so that the financial exchanges and contacts among regions are more frequent. It also shows that, besides considering the impact of geographical distance, the economic distance factor should be taken into consideration while we are researching the spatial effects of fiscal decentralization on regional financial innovation; in addition to the consideration of the impact of geographical distance, the economic distance factor should be considered.

\section{Conclusions and Enlightenments}

Based on the panel data of 281 prefecture-level cities in China covering the period of 2003-2012, the regional financial efficiency is measured by the superefficiency SBM model; the geographic distance weight matrix and economic-geography mixed weight matrix which can reflect the regional similarity are introduced into the SDM, and the spatial effects of the fiscal expenditure and revenue decentralization on regional financial efficiency under province are investigated, as well as the strategic financial competition arising from it. Based on the results of previous empirical analysis, we can draw the following basic conclusions.

First, the geographical distribution of China's prefecturelevel cities' financial efficiency presents significant features of time inertia and spatial dependency. Financial development and innovation among regions, particularly neighboring regions, is not independent but shows significant spatial spillover effects. The financial efficiency of the local region will be significantly affected by the financial efficiency of adjacent regions. The spatial effect is increasingly obvious in the process of financial development and innovation, and the size of the spillover effects is closely related to spatial weight (which is used to measure regional similarities) and mainly shows that there is competition for financial efficiency among regions with similar economic attributes and adjacent regions.

Second, it cannot be ignored that the institutional factors especially fiscal decentralization have effect on the financial efficiency, and the factors have a decisive role in the allocation of financial resource and the regional distribution of financial innovation. The improvement of fiscal decentralization level will help to attract more financial resources, thereby promoting an increase in financial efficiency. The improvement of the financial autonomy in neighboring jurisdictions will reduce the financial resources flowing into the local region and suppresses the occurrence of the local financial innovation. In addition, there exist significant spatial spillover effects of 
financial development and efficiency caused by fiscal decentralization. The scope of spatial spillovers is mainly reflected in two aspects. Thus, the local governments' competition not only strongly increases the financial efficiency of the region but also accelerates interregional competition for financial efficiency.

Third, fiscal expenditure decentralization and revenue decentralization's impact on regional financial efficiency have nonequilibrium characteristics. First of all, there exists asymmetry between fiscal expenditure decentralization and revenue decentralization's impact on regional financial efficiency. Fiscal expenditure decentralization can promote optimization of the fiscal expenditure structure, and fiscal revenue decentralization can increase the local governments' revenue share so as to provide positive incentives [43]; both of them have a positive and promoting effect on the improvement of local financial efficiency and such effect largely depends on the symmetry between the fiscal expenditure and revenue decentralization. If it is asymmetric between their property rights and the expenditure responsibilities under fiscal decentralization system, the local governments may make excessive intervention to regional financial resources allocation to meet their own demands for financial resources. Next, there exists nonconformance between fiscal expenditure decentralization and revenue decentralization's impact on financial efficiency in neighboring regions. Compared with the fiscal expenditure decentralization, the fiscal revenue decentralization has more apparent inhibitory effect on the financial efficiency in neighboring regions.

Our research conclusions have important policy implications that illuminate the relationship between fiscal decentralization and financial efficiency.

(1) The regional financial efficiency is closely related to the location and the economic development of the surrounding cities. The regional financial efficiency is affected not only by the financial development and innovation in neighboring regions, but also by the impact of the structural differences among regions. In this case, breaking the administrative monopoly of local protectionism and carrying on the "richening neighbor" policy of financial development are the best choices for the local government to develop the regional economy. When making policies of financial development, local governments need to consider their own economic development environment and economic features in neighboring regions and strengthen communication and coordination with the surrounding regions, so as to avoid the possible contradictions and conflicts on financial development policies among regions.

(2) The spatial spillover effects of the regional financial efficiency should be divided into two kinds of effects including global geographic spillover effects and local geographic spillover effects. In order to promote the increase of financial efficiency in a better way, it should also be based on the hierarchy of spatial effect of and the degree of spillover effect to define the relationship between the government and the market and central and local governments and among the local governments and their role in regional financial development and innovation, so as to better promote financial efficiency.
(3) There is a two-way interactive mechanism between the fiscal system and financial development; such effects may affect the behaviors of the local governments and the allocation of resources and ultimately act on macroeconomic performance [10]. Under the fiscal decentralization system, the strategic competitive behaviors among local governments significantly affect the liquidity of financial resources and the occurrence of financial innovation; the local governments' expansion of fiscal expenditure and revenue shortfall become the main driving force of each region competing for financial resources. In order to better play the role of incentives and constraints of fiscal competition mechanism under the fiscal decentralization system, and avoid the negative impact brought by the vicious interregional strategic financial competitive behaviors on the regional economic development, the local governments' short-sighted behaviors should be strictly regulated, and then the interregional financial cooperation with mutual benefit as the core should be actively promoted.

(4) Constructing a scientific and rational framework for fiscal decentralization will be an important force to accelerate effectively the improvement of regional financial efficiency; China's future subprovincial fiscal decentralization reform should adapt to the new normal financial development and further rationalize the provincial and subprovincial fiscal decentralization system, to ensure a balanced and appropriate fiscal expenditure and revenue decentralization. On one hand, we should weaken local governments' negative intervention in financial system by reducing local governments' financial pressure caused by the asymmetry between the fiscal resources and expenditure responsibilities. On the other hand, we should also actively play the function of fiscal system to adjust the financial development and innovation and fully play public finance's role in promoting the flowing of financial resources among regions, the balanced development of regional finance, and the improvement of financial efficiency.

\section{Competing Interests}

There are no competing interests in regard to the content discussed in this paper.

\section{Authors' Contributions}

All authors conceived and designed the research; Xiaomei Hu collected and processed the data; Jianmin Liu analyzed the data and interpreted the results; all authors were also involved in writing the paper and have all approved the submitted form.

\section{Acknowledgments}

The research of this paper is jointly funded by the National Social Science Foundation of China under Project no. 14BJY159 and the Hunan Philosophy and Social Science Fund Project under Grant no. 13JD09. The authors gratefully acknowledge the support of Jinguang $\mathrm{Wu}$ from Hunan University of Finance and Economics, China. 


\section{References}

[1] J. Zhang and X. Jin, "Re-examine of the relationship between China's financial deepening and productivity: 1987-2001," Economic Research Journal, vol. 11, pp. 35-43, 2005.

[2] K. Chen, A. L. Hillman, and Q. Y. Gu, "Fiscal centralization and changes of local governments' behaviors-from 'hands for help' to 'hands for grab"' China Economic Quarterly, vol. 1, pp. 111-130, 2002.

[3] L. Zhou and Z. M. Wang, "Empirical analysis of regional financial development of China and economic growth: 19782000," Financial Research, vol. 10, pp. 1-13, 2002.

[4] L. Zhou, "'Second finance' of China's financial industry and financial division during the reforming period," The Journal of World Economy, vol. 6, pp. 72-79, 2003.

[5] L. Zhou, "Gradual transition, state capacity and fiscal function of finance," Journal of Finance and Economics, vol. 2, pp. 26-37, 2005.

[6] E. L. He and W. Liu, "Financial capital, local governments' intervention and industrial structure-an empirical analysis based on the data of central regions," Economic Issues, vol. 5, pp. 37-40, 2011.

[7] X. L. Dou and W. J. Wang, "The differences and trends of Chinese regional financial development, and local governments' behavior and analysis of tax sharing reform on the differences and trends of Chinese regional financial development," Shanghai Finance, vol. 2, pp. 9-15, 2011.

[8] J. Zhang and K. R. Shen, "Local government intervention, regional financial development and the transformation of China's economic growth mode-an empirical study under the fiscal decentralization system," Nankai Economic Studies, vol. 6, pp. 122-141, 2008.

[9] G. Chen, X. G. Yin, and Y. Pan, "China's financial development, tax sharing reform and economic growth," Financial Research, vol. 2, pp. 99-109, 2006.

[10] P. P. Ding and Y. Fu, "Behaviors of local governments, the relationship of fiscal and finance and macroeconomic volatility associated with China-an analysis under Chinese-style fiscal decentralization system," Comparative Economic \& Social Systems, vol. 6, pp. 87-97, 2012.

[11] X. G. Yin, G. Chen, and Y. Pan, "Tax sharing reform, local governments' intervention and financial development efficiency," Journal of Finance and Economics, vol. 10, pp. 92-101, 2006.

[12] M. G. Yu and H. B. Pan, "Government intervention, the rule of law, financial development and bank loans of state-owned enterprises," Financial Research, vol. 9, pp. 1-23, 2008.

[13] D. X. Wang, J. Liu, and L. Li, "Fiscal decentralization, bank credit and total factor productivity," Journal of Finance and Economics, vol. 4, pp. 69-80, 2011.

[14] Y. X. Jiang and R. B. Jiang, "Regional financial innovation: efficiency evaluation, environmental impact and gap analysis," Journal of Zhejiang University (Humanities and Social Sciences), vol. 43, no. 4, pp. 52-65, 2013.

[15] H. W. Yang, L. W. Cheng, Y. Xu, and Y. W. Qi, "Measure and influencing factors of financial resources allocation efficiency under fiscal decentralization system based on super-efficiency DEA-TOBIT two-step method," Journal of Jiangxi Normal University (Natural Sciences Edition), vol. 6, pp. 587-592, 2014.

[16] N. Shen, F. Z. Liu, and J. Q. Zhao, "Fiscal decentralization, financial deepening and regional international poverty prone to develop," Finance \& Trade Economics, vol. 1, pp. 41-46, 2006.
[17] Q. Y. Du, G. P. Li, and N. Shen, "Financial efficiency and optimization of the regional industrial structure under the current fiscal system," Xinjiang Social Science, vol. 4, pp. 16-21, 2006.

[18] T. Feng, Y. W. Song, and Y. Lu, "Fiscal decentralization, local governments' behavior and regional financial development," Journal of Xian Jiaotong University, vol. 5, pp. 20-27, 2007.

[19] Y. A. Zhou, X. J. Ma, and J. Y. Zhao, "Government behaviors, financial development and economic growth," Henan Social Sciences, vol. 1, pp. 55-60, 2007.

[20] C. Hao, "Development of financial intermediation and economic growth: the Chinese experience," China Economic Review, vol. 17, no. 4, pp. 347-362, 2006.

[21] J. Zhang, Fiscal Decentralization, Regional Financial Development and China's Economic Growth Performance, Nanjing University Press, Nanjing, China, 2011.

[22] Y. J. Yao, "Government intervention, the development of financial intermediation and economic growth," Journal of Finance and Economics, vol. 8, pp. 52-58, 2010.

[23] X. Wang and L. Li, "Fiscal decentralization and regional financial development: the theoretical and empirical analysis from the perspective of central government," Public Finance Research, vol. 4, pp. 31-35, 2012.

[24] W. L. Zhang and C. L. Qin, "Financial development, fiscal decentralization and regional economic differences," Economic Geography, vol. 1, pp. 583-588, 2009.

[25] Y. Ma, J. Li, and B. Chen, "Provincial differences in Chinese fiscal decentralization, financial development, industrialization and economic growth," Economic Theory and Business Management, vol. 2, pp. 5-19, 2015.

[26] Y. X. Jiang and R. B. Jiang, "The spatial external effects of regional financial innovation: financial competition and financial agglomeration," Social Science Front, vol. 3, pp. 79-84, 2014.

[27] K. Tone, "A slacks-based measure of super-efficiency in data envelopment analysis," European Journal of Operational Research, vol. 143, no. 1, pp. 32-41, 2002.

[28] Y. Q. Lu and D. G. Zhang, "China’s regional financial efficiency and differences of efficiency measurement," Economic Geography, vol. 1, pp. 96-101, 2012.

[29] A. N. Berger and D. B. Humphrey, "Efficiency of financial institutions: international survey and directions for future research," European Journal of Operational Research, vol. 98, no. 2, pp. 175-212, 1997.

[30] Y. J. Yao, "Empirical analysis of financial development and urban-rural income gap," Journal of Finance and Economics, vol. 2, pp. 49-59, 2005.

[31] Q. Li, J. Song, E. Wang, H. Hu, J. Zhang, and Y. Wang, "Economic growth and pollutant emissions in China: a spatial econometric analysis," Stochastic Environmental Research and Risk Assessment, vol. 28, no. 2, pp. 429-442, 2014.

[32] J. P. LeSage and R. K. Pace, Introduction to Spatial Econometrics, CRC Press Taylor \& Francis Group, Boca Raton, Fla, USA, 2009.

[33] Q. W. Guo and J. X. Jia, "Fiscal decentralization, organizational structure of local governments and the size of government expenditure," Economic Research Journal, vol. 11, pp. 59-87, 2010, http://www.cnki.com.cn/Article/CJFDTotal-JJYJ201011008 .htm.

[34] F. Gong and X. Lei, "The measurement of Chinese-style fiscal decentralization," Statistical Research, vol. 10, pp. 47-55, 2010.

[35] G. Fan, X. L. Wang, and H. P. Zhu, Chinese Marketing Index: Regional Marketing Process in 2011, Economic Science Press, Beijing, China, 2011. 
[36] S. S. Rosenthal and W. C. Strange, "Geography, industrial organization, and agglomeration," The Review of Economics and Statistics, vol. 85, no. 2, pp. 377-393, 2003.

[37] S. Park Yoon, International Banking and Financial Centers, Kluwer Academic, Boston, Mass, USA, 1989.

[38] B. Y. Qiao, J. Y. Fan, and X. Y. Feng, "China’s fiscal decentralization and compulsory primary education," Social Sciences in China, vol. 6, pp. 37-46, 2005.

[39] W. J. Wang and C. L. Qin, "Regional differences in the behaviors of local governments and growth effect of fiscal decentralization based on the analysis of judgment, hypothesis and testing," Management World, vol. 1, pp. 9-21, 2008.

[40] J. K. Brueckner, "Strategic interaction among governments: an overview of empirical studies," International Regional Science Review, vol. 26, no. 2, pp. 175-188, 2003.

[41] F. Revelli, "On spatial public finance empirics," International Tax and Public Finance, vol. 12, no. 4, pp. 475-492, 2005.

[42] N. Shen and T. Y. He, "Financial efficiency and regional economic growth from the perspective of fiscal decentralization," Reform, vol. 1, pp. 61-65, 2006.

[43] J. M. Liu, X. M. Hu, and J. G. Wu, "The threshold effect of sub-national fiscal decentralization revenue and expenditure decentralization on provincial industrial transformation and upgrading based on the data of 14 cities in Hunan Province," Public Finance Research, vol. 8, pp. 49-52, 2014. 


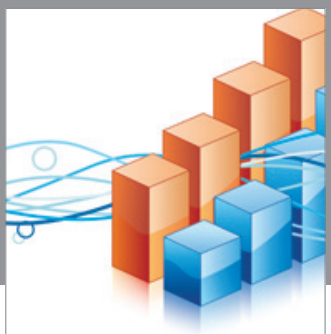

Advances in

Operations Research

vatem alat4

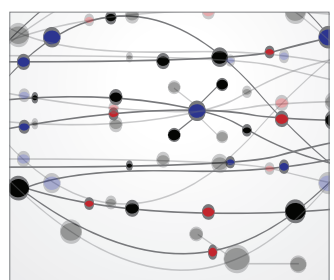

\section{The Scientific} World Journal
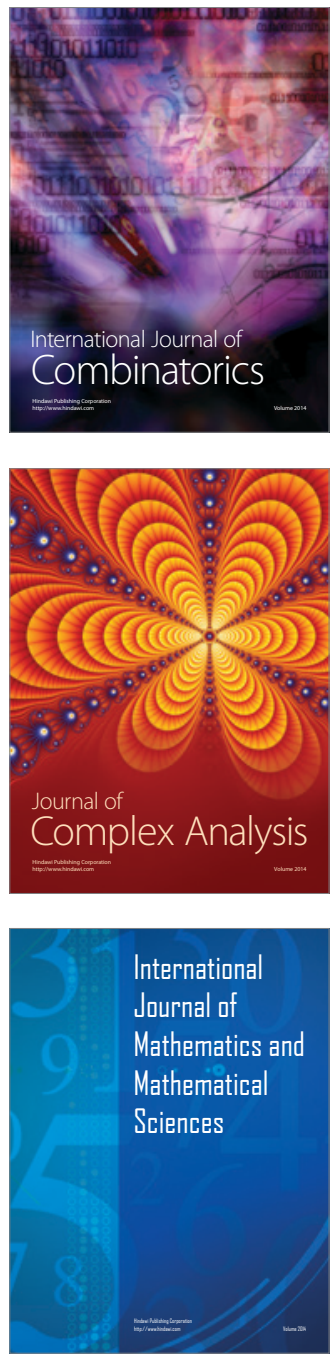
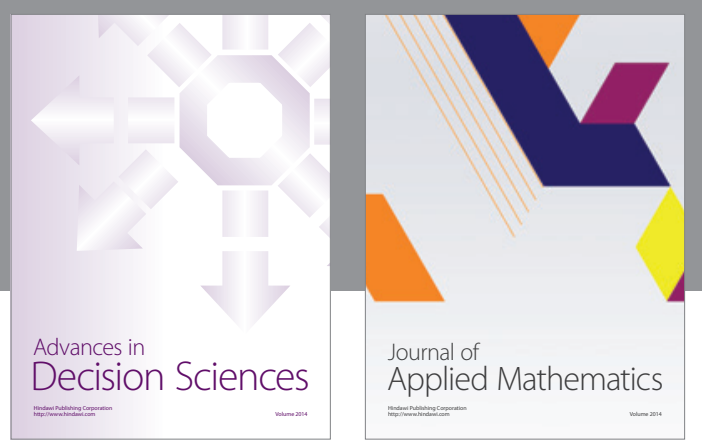

Algebra

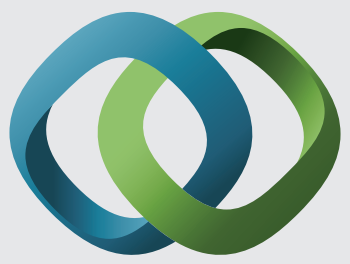

\section{Hindawi}

Submit your manuscripts at

http://www.hindawi.com
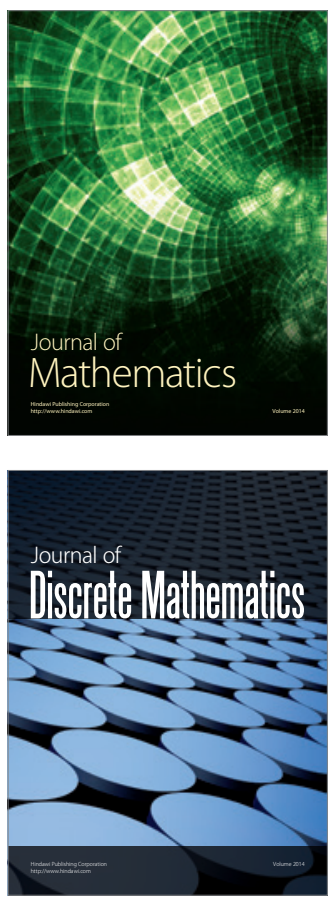

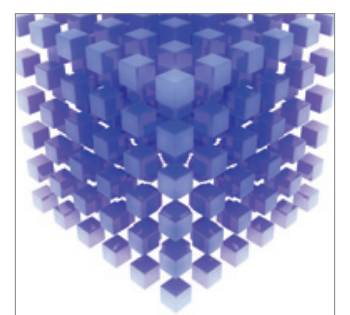

Mathematical Problems in Engineering
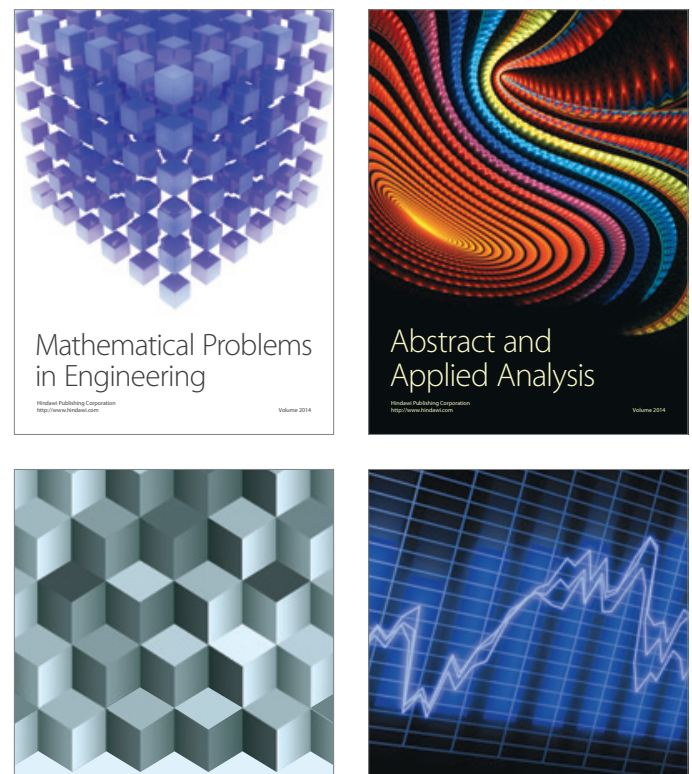

Journal of

Function Spaces

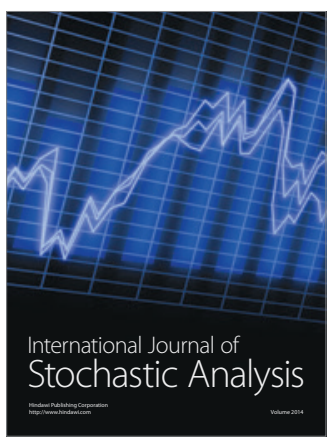

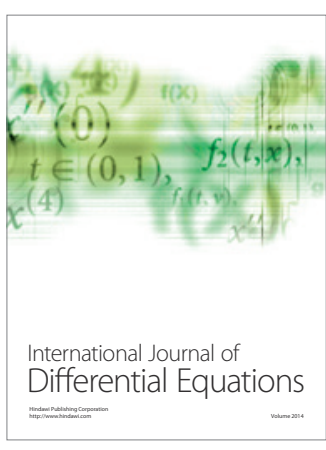
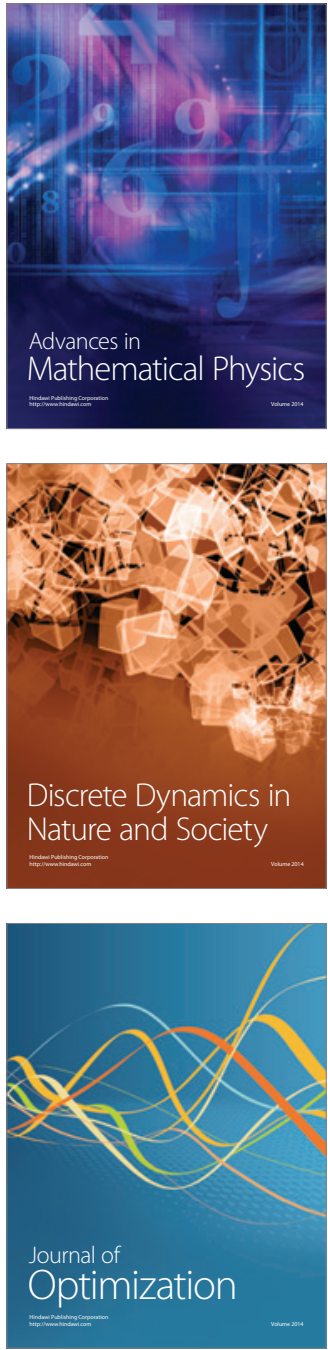